\title{
NUCLEAR FACTITTIES LICENSING: A WORD MORE
}

\section{DAVID F. CAVERS}

My article, with which Professor Davis has differed with accustomed vigor, represents an attempt to examine a complex, difficult, and controversial problem as to which a number of informed and thoughtful people entertain a variety of views. Such a situation is not conducive to debate. A thorough airing of the issues would require "equal time" for AEC Commissioner Olson or AEC General Counsel Naidin, who disagree strongly with my views on the structure of the AEC and probably on the hearing process as well but who disagree even more strongly with Professor Davis on the latter issue. And perhaps Messrs. Berman and Hydeman, who carried out a long and careful study of the subject for the University of Michigan Law School's Atomic Energy Project, would also want to be heard. They disagree with me as to the AEC's structure but also with Professor Davis and the Commission. With three Other Views and one or two Words More in hand, we'd have a true Donnybrook!

Since my position seems unclear, ${ }^{1}$ as well as mistaken, to Professor Davis, I should like to add a few more words on the principal matters he has raised: the nature of the review proceedings and the combination of promotional, developmental, and regulatory responsibilities in the Commission.

No one could have discussed with knowledgeable people over a period of months the problems of $A E C$ decisionmaking in reactor licensing cases, as did the Joint Committee's staff and their consultants, former AEC General Counsel William Mitchell and I, without growing concerned by the apparent overjudicialization of the process. Yet, if one thinks it wise, as I do, to require, even in an uncontested case, the holding of an oral public proceeding before decisionmakers (as distinguished from the press-conference type of hearing Professor Davis

1 Professor Davis is entitled to associate my views in general with those of the Joint Committee staff study. 1 STAFF OF JOINT COMM. ON ATOMIC ENERGY, 87TH Cong., 1st Sess., Improving the AEC Regulaatory Process (Jt. Comm. Print 1961). The study group worked closely together, and I helped to write the report. I found correspondence with Professor Davis in connection with our articles helpful in developing my own ideas as well as in furthering my understanding of his. On some points my present beliefs still lack the degree of finality that I observe in Professor Davis'. The careful reader might discern wider areas of agreement between Professor Davis' views and mine than Professor Davis will allow. 
recommends), some procedure has to be developed for the proceeding. Normally the proceeding would entail the presentation, and (hopefully) a searching discussion, of facts, including physical theory and expert opinions. Given its purpose, I believe this process can aptly be called a "review," though I would not conceive it as resembling at all closely the judicial review of administrative action. Obviously any presentation of facts to a board has some resemblance to a trial, but I would not call this a "trial-type hearing," for one reason because its purpose is not to settle a dispute. I don't suppose Professor Davis would want to label it a "trial-type hearing," but, if he should wish to do so, that certainly is his privilege-it's his label.

Professor Davis complains, with some justice, of the generality of the criteria I have used to suggest the different modes of procedure which might be developed for the conduct of these "review" proceedings before a technically qualified board, a matter not considered in detail in the Joint Committee staff study. The reason for my failure to lay down specific guidelines is simply this: I don't know enough. I wonder if even Professor Davis does. The problem is in many ways a distinctive one; however much one may cherish the traditional modes of hearings ("trial-type," "argument," and "mixed"), they don't provide satisfying specific answers here.

I am somewhat comforted in acknowledging the deficiency in my knowledge by the fact that a leading lawyer with extensive experience in reactor licensing once urged that a study of the problem of how to conduct these review proceedings be undertaken at the Harvard Law School. I cite this only as evidencing his concern with the problem and lack of assured answers to the questions it raises. Although I share his confidence in my colleagues who are expert in administrative law, if they were available for the study, yet I think, as I suggested in my article, the best answers could be reached by the Board itself, provided, of course, it felt free to experiment and was not confined to familiar patterns.

With respect to the combination of responsibilities in the Commission, a problem that poses a very difficult question of judgment on which the views of experienced observers differ widely, I should like to make two comments on the deficiencies in my treatment that Professor Davis has reported.

I wonder how I was able to conceal my personal views on this issue from Professor Davis while at the same time putting forward the concept of the independent Atomic Safety and Licensing Board ${ }^{2}$

2 Though Professor Davis has accurately listed ways in which the Board proposed by the study is independent of the Commission, it may be useful to recall two ways in which the Commission and its staff would continue to participate in the regulatory 
which he assails with such gusto. Be that as it may, perhaps I have erred in failing to develop more fully the position (which Professor Davis does not seem adequately to appreciate) that the atomic power industry is exceedingly sensitive, indeed vulnerable, to public opinion. Moreover, a public educated in the dangers of fallout may tend to overanxiety-as I think was apparent in disposal matters on Cape Cod, in Texas, in California, and on the French Riviera. Though Judge Edgerton's requirement in the Power Reactor Dev. Co. case that the AEC find "compelling reasons" to justify locating a big reactor near a large city overstates the law, ${ }^{3}$ yet, as a matter of cold fact, an atomic power or test reactor exists by the grace of the exposed communities. If the fears of such a community are sufficiently aroused, the reactor in all probability will not be built. Measures that enhance public confidence on questions of reactor safety are therefore not lightly to be dismissed. Moreover, the AEC commitment created when the staff presents safety arguments designed to reassure an exposed community ought not to be confused with the very different process involved when a technically qualified board hears staff arguments before reaching its independent decision; selling a customer is not the same as convincing an appraiser.

Professor Davis complains that I do not make clear whether I think the combination of responsibilities will lead to relaxation of safeguards or overemphasis on them. Either result could happen; if I had to guess, I should say the former would be more frequent. My diffculty is one that I should suppose even the individual Commissioners would share. I assume them to be honest and conscientious, but I believe it would be well-nigh impossible for a Commissioner, in a close case, to tell whether he was leaning forward, leaning backward, or achieving a precise verticality in reaching his decision on the safety issue with respect to a reactor which he-or even his predecessors-had worked long and prayerfully to get under way.

process. (1) The staff making the original safety evaluation and presentation to the Board would be the Commission's staff, not the Board's. (2) The Commission would have final authority in rulemaking and so could set licensing standards that would be binding on the Board. See Cavers, Administrative Decisionmaking in Nuclear Facilities Licensing, 110 U. PA. L. REV. 330, 363-67 (1962).

3 International Union of Elec. Workers v. United States, 280 F.2d 645, 651-52 (D.C. Cir. 1960), rev'd sub nom. Power Reactor Dev. Co. v. International Únion of Elec. Workers, 367 U.S. 396 (1961).

4 Professor Davis objects that I do not give enough weight to the internal separation achieved in the AEC. This separation is not effected in the staff until a hearing is scheduled, that is, after the staff has decided to approve the reactor. It is important to have free interchange between the developmental and regulatory staffs.

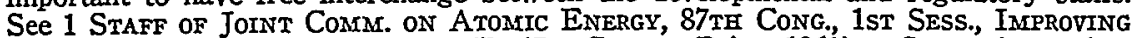
THE AEC Reguzatory Process 67 (Jt. Comm. Print 1961). Separation, when effected, operates mainly to impair decisionmaking at higher levels as both Professor Davis and I agree. Surely I need not detail how the combination of responsibilities 
It is this consideration which consoles me when the inadequacy of my investigation on this point is asserted by Professor Davis. Isn't this rather like a number of situations in which the law, taking account of the subtleties of human motivation and our difficulty in reconciling conflicting goals, lays down a rule which eliminates the problem by eliminating the conflict? The wisdom of this traditional way of dealing with a problem of this sort can perhaps be most readily demonstrated by looking back at the kind of inquiry Professor Davis would have had me make. Only a hardened optimist among behavioral scientists would expect to solve the problem on the basis of the answers that the study Professor Davis proposes would extract.

I shall repress the temptation to delve into narrower points on which I feel Professor Davis and I are still at odds and add only a word more about the Holifield-Pastore bill on which Professor Davis insists we disagree. He observes that "the sponsors have at least for a time rejected the Cavers proposal for an independent board," 5 a statement of political fact which is open to exception only in its designation of the Joint Committee staff recommendation as "the Cavers proposal." Perhaps he thinks me unrealistic in hoping that the hearings may reveal the Commission ready to give the device of a technically qualified board a fair trial and, admonished by legislative history written by the watchful Joint Committee staff, willing to approach its procedural problems in nuclear facilities licensing in a less formal, more experimental frame of mind, even though the Commission may still shrink from following Professor Davis' advice to call in the management engineers.

at the Commission level could affect AEC decisionmaking even-or perhaps especially -if the Commission were never to take a case on formal review. However, the problem must be examined on the supposition that the Commission is taking the more active role that Professor Davis would have it assume.

5 Davis, Nuclear Facilities Licensing: Another View, 110 U. PA. L. REv. 371, 387 n.44 (1962). 